\title{
WHICH IS MORE EFFECTIVE, A MIND MAP OR A CONCEPT MAP LEARNING STRATEGY?
}

\author{
I Wayan Redhana ${ }^{1 *}$, Kadek Widiastari ${ }^{1}$, Achmad Samsudin ${ }^{2}$, Irwanto ${ }^{3}$ \\ ${ }^{1}$ Universitas Pendidikan Ganesha, Indonesia \\ ${ }^{2}$ Universitas Pendidikan Indonesia, Indonesia \\ ${ }^{3}$ Universitas Negeri Jakarta, Indonesia \\ *email: wayan.redhana@undiksha.ac.id
}

\begin{abstract}
A mind map and a concept map learning strategy are two learning strategies that are often used to improve students' learning achievement. This study aimed to describe the differences in learning achievement between students who studied with a mind map learning strategy and those who used the concept map learning strategy, as well as the students' responses toward the learning strategy applied. This type of study was a quasi-experiment with a pretest-posttest control group design. The methods used in this study were a test and a questionnaire. Data of students' learning achievement were analyzed using inferential statistics of covariance analysis, while data of students' responses were analyzed by descriptive statistics. The results of the study indicated that there were significant differences in the learning achievement between students who used the mind map learning strategy and those who studied with the concept map learning strategy. Those who used the mind map learning strategy had better achievements than those using the concept map learning strategy. In addition, the students' responses were more positive toward the mind map learning strategy than to the concept map learning strategy.
\end{abstract}

\section{Keywords: concept maps, learning achievement, learning strategy, mind maps.}

\section{MANA YANG LEBIH EFEKTIF, STRATEGI PEMBELAJARAN PETA PIKIRAN ATAU PETA KONSEP?}

\begin{abstract}
Abstrak: Strategi pembelajaran peta pikiran dan peta konsep merupakan dua strategi pembelajaran yang sering digunakan untuk meningkatkan prestasi belajar siswa. Penelitian ini bertujuan mendeskripsikan perbedaan prestasi belajar siswa yang belajar menggunakan peta pikiran dan prestasi belajar siswa yang menggunakan peta konsep serta respons siswa terhadap strategi pembelajaran yang diterapkan. Penelitian ini merupakan penelitian eksperimen kuasi dengan pretest-posttest control group design. Metode yang digunakan adalah tes dan angket. Data prestasi belajar siswa dianalisis menggunakan statistika inferensial analisis kovarian, sedangkan respons siswa dianalisis menggunakan statistika deskriptif. Hasil penelitian menunjukkan bahwa terdapat perbedaan yang signifikan prestasi belajar antara siswa yang belajar menggunakan strategi peta pikiran dan siswa yang belajar menggunakan strategi pembelajaran peta konsep. Siswa yang belajar menggunakan strategi peta pikiran menunjukkan prestasi belajar yang lebih baik daripada siswa yang belajar menggunakan strategi pembelajaran peta konsep. Respons siswa lebih positif terhadap strategi pembelajaran peta pikiran dibandingkan dengan respons siswa terhadap strategi pembelajaran peta konsep.
\end{abstract}

Kata Kunci: peta konsep, prestasi belajar, strategi pembelajaran, peta pikiran.

\section{INTRODUCTION}

The learning process is an important component in the educational system. The learning process is an effort to apply learning approaches, models, strategies, methods, and techniques to present subject matter content so that students can understand it properly. Assessment is also an integral part of the learning process. Through a good learning process, inputs can be transformed into qualified graduates (human resources). The quality of human resources will be able to drive a country's economy. Thus, the quality of human resources has a very important position for the progress of a country.

Given the importance of the learning 
process in producing the quality of human resources, all parties, especially teachers, must pay special attention to the learning process. Efforts to improve the quality of the learning process can be done in several ways. One of them is by applying appropriate learning approaches, models, strategies, methods, and techniques. A mind map and a concept map learning strategy are two learning strategies that concern researchers (Chiou, Lee, Tien, \& Wang, 2017; Fadillah, Dewi, Ridho, Majid, \& Prastiwi, 2017; Herlanti, Mardiati, Wahyuningtyas, Mahardini, Iqbal, \& Sofyan, 2017).

The mind maps are recording techniques developed by Tony Buzan in the late 1960s (Adodo, 2013). They illustrate the relationship among ideas involving the thickness of lines, colors, images, and diagrams creatively (Adodo, 2013). They can help students utilize their knowledge to build new knowledge in their minds so that they can make conceptual changes (Liu, Zhao, Ma, \& Bo, 2014). In addition, they are known to increase memory retention and increase students' motivation (Liu et al., 2014). On the other hand, the concept maps are schemes that show relationships between concepts (Brinkerhoff \& Booth, 2013). They are learning strategies that are compatible with meaningful learning (Kilic \& Çakmak, 2013). They are made by writing concepts in a box or circle and showing relationships between concepts using labeled lines (Karakuyu, 2010; Brinkerhoff \& Booth, 2013; Kilic \& Çakmak, 2013). In addition, they also allow students to receive and store information more efficiently (Arokoyu \& Obunwo, 2014).

Creating the mind and the concept maps can be done by asking questions $5 \mathrm{~W} 1 \mathrm{H}$ (what, why, when, where, who, and how). These questions help to create active learning activities because students can find information through reading books or other information media and discussing them in a group to find answers to questions. This is in accordance with the theory of constructivism, namely, understanding of contents of subject matters based on the experience of students themselves (Ültanır, 2012). In addition, active learning can help students in (a) thinking critically or creatively, (b) talking to classmates in small groups or in the whole class, (c) expressing ideas through writing, (d) exploring personal attitudes and values, (e) giving and receiving feedback, and (f) reflecting the learning processes (Eison, 2010).

To optimize the application of mind maps or concept maps, these learning strategies are often combined with several learning models, such as lesson study-based contextual learning models with mind maps (Fadillah et al., 2017), project-based learning models with mind maps (Susilawati, Hernani, \& Sinaga, 2017), guided inquiry learning model with mind maps (Prastiwi, Haryani, \& Lisdiana, 2018), computerassisted concept map learning model (Liu, Chen, \& Chang, 2010), technology-based concept map learning model (Hwang, Wu, \& Kuo, 2013), an integrated concept map learning model (Hwang, Kuo, Chen, \& Ho, 2014), and a problem-based learning model with concept maps (Si, Kong, \& Lee, 2018).

Measuring the effectiveness of mind map or concept map learning strategies in improving the students' learning achievement is done by comparing each of these learning strategies with the conventional or traditional learning strategy. The results showed that the mind map learning strategies are more effective than the conventional learning strategy in increasing the students' learning achievement (Awad \& Hegazy, 2015; Tarkashvand, 2015; Herlanti et al., 2017; Mahasneh, 2017). Likewise, the mind map learning strategies are more effective than the conventional learning strategy in improving programming performances, problem solving skills, and metacognitive knowledge (Ismail, Ngah, \& Umar, 2010), cognitive knowledge structures (Dhindsa, Kasim, \& Anderson, 2011), critical thinking skills (D'Antoni, Zipp, Olson, \& Cahill, 2010; Khodadady \& Ghanizadeh, 2011; Adodo, 2013), creative thinking skills (Adodo, 2013; Zubaidah, Fuad, Mahanal, \& Suarsini, 2017), learning motivation (Tanriseven, 2014; Prastiwi et al., 2018), independent learning (Tanriseven, 2014), scientific process skills (Prastiwi et al., 2018), and collaborative learning (Chang, Chiu, \& Huang, 2018).

On the other hand, the results showed that the concept map learning strategies are more effective (Chawla, 2015; Tarkashvand, 2015; Chiou et al., 2017). Other research results also showed that the concept map learning strategies are better than the conventional learning strategy in increasing attitudes towards science (Karakuyu, 2010), learning motivation (Hwang, 
Shi, \& Chu, 2011), critical thinking skills (Lestari, Saryantono, Syazali, Saregar, Madiyo, Jauhariyah, \& Umam, 2019), and learning interest (Lestari et al., 2019). In addition, the concept map learning strategies can reduce cognitive load (Hu \& Wu, 2012).

However, research results related to the comparison of mind map learning strategies and concept map learning strategies in improving the students' learning achievement are still limited and have not shown consistent results. Abbas, Sharaf, \& Elsayed (2018) reported that there was no significant difference in concept understanding between students who were taught with the mind map learning strategies and students who were taught with the concept map learning strategies. This is probably due to the researchers assumed that by knowing the advantages or effectiveness of the proposed new learning models or strategies against the conventional learning models or strategies, the study has been considered complete. Or, the researchers may also be less interested in comparing two or more learning models or strategies that have common advantages.

This study aims to compare the effectiveness of two learning strategies, namely, mind maps and concept maps, which are both more effective in increasing the students' learning achievement than the conventional learning strategy. By knowing which learning strategy is more effective in increasing the students' learning achievement, teachers can choose the right learning strategy in making lesson plans. In addition, students will get better learning experiences in increasing their learning achievement.

\section{METHOD}

\section{Types of Research}

This type of study was a quasi-experiment using a pretest-posttest non-equivalent control group design. In this study, two experimental groups were used, namely Group 1 and 2, and both groups were given the test before treatment (pretest) and after the test after treatment (posttest).

\section{Population and Samples}

The study was conducted at one of the high schools in Buleleng district, Bali, Indonesia. This school is located in Singaraja city and is a private school which is quite a favorite in which there are quite a lot of prospective students. This study was conducted in class X. This school had class $\mathrm{X}$ as many as nine classes. For the purposes of experimental research, two existing classes were needed so as not to interfere with the ongoing learning process. Sampling was done using a cluster sampling technique. Based on the technique, it was obtained two classes which would be assigned respectively as Experimental Group 1 and Experimental Group 2. The Experimental Group 1 consisted of 26 students (10 boys and 16 girls), while the Experimental Group 2 consisted of 24 students (11 boys and 13 girls). Students who participated in this study were 15-16 years old. They come from a city environment. Students' understanding of chemistry was still quite limited. This was because they were still in the early class (class $\mathrm{X})$ in high school.

\section{Procedures of Data Collection}

Before learning, both the Experimental Group 1 and 2 were given a learning achievement test (pretest). The test execution time was 90 minutes. This test had met the criteria of validity, reliability, difficulty level, and different power index.

In the implementation of learning, the Experimental Group 1 and 2 were taught respectively with a mind map and a concept maps learning strategy. Both groups were taught by the same teacher on the topic of hydrocarbons. Overall there were six stages of learning of these two learning strategies. The implementation of these two learning strategies lasted $6 \times 45$ minutes.

The learning stages of the mind map learning strategy were as follows. First, the teacher conveyed the learning objectives and the scope of the materials to be studied. Second, students make questions using the $5 \mathrm{~W} 1 \mathrm{H}$ strategies (what, when, who, where, why, and how) in accordance with the learning objectives and the materials being studied. Third, students found ideas and conceptual explanations through discussion activities in small groups (4-5 students) to answer the questions posed in Stage 2. This information gathering was done through various sources. Fourth, one of the groups presented their ideas in a class discussion and the other groups responded. Fifth, students 
mapped answers to questions in the form of a mind map. Finally, students displayed the results of their mind maps.

On the other hand, the learning stages of the concept map learning strategy were as follows. First, students listen to the learning objectives and material coverage. Second, students generated a number of questions to understand the learning materials being studied and these questions were in accordance with the learning objectives. Questions were made using the $5 \mathrm{~W} 1 \mathrm{H}$ concept. Third, students discussed in small groups (4-5 students) to find answers to questions in stage 2 using various learning resources. Fourth, students reported the results of their group discussions in class discussions to get responses from other groups. Fifth, students created a concept map based on the answers to the questions. Finally, students showed off the concept maps that were generated from group discussions.
After implementing the two learning strategies in each experimental group, students' learning achievement was measured by a learning achievement test (posttest). The test used after treatment was the same as it used before treatment. The test ran for 90 minutes.

\section{Learning Tools and Research Instruments}

Learning tools used were learning implementation plans and students' worksheets. Meanwhile, an instrument used to collect data of learning achievement test for the topic of hydrocarbon compounds. This test was developed by researchers. The blueprint of learning achievement test is shown in Table 1. Based on Table 1, it appeared that the test consisted of 15 objective items and 10 essay items.

Before it was used to measure the students' learning achievement, this test was tested validities, reliability, levels of difficulties, and

Table 1. Blueprint of Learning Achievement Test

\begin{tabular}{|c|c|c|c|}
\hline Basic Competencies & Indicators of Competency Achievement & Type of Test & $\begin{array}{l}\text { Number } \\
\text { of Items }\end{array}$ \\
\hline \multirow{4}{*}{$\begin{array}{l}\text { Describing the } \\
\text { peculiarities of } \\
\text { carbon atoms in } \\
\text { forming hydrocarbon } \\
\text { compounds }\end{array}$} & $\begin{array}{l}\text { Analyzing the elements } \mathrm{C}, \mathrm{H} \text {, and } \mathrm{O} \text { in carbon } \\
\text { compounds }\end{array}$ & Essay & 1 \\
\hline & $\begin{array}{l}\text { Describing the peculiarities of the carbon atom in } \\
\text { carbon compounds }\end{array}$ & Essay & 1 \\
\hline & Identifing primary, secondary, tertiary, and & Objective & 1 \\
\hline & quaternary $\mathrm{C}$ atoms & Essay & 1 \\
\hline \multirow{13}{*}{$\begin{array}{l}\text { Classifying } \\
\text { hydrocarbons based } \\
\text { on their structures } \\
\text { and relationships to } \\
\text { the properties of the } \\
\text { compound }\end{array}$} & Grouping hydrocarbons based on bond saturation & Essay & 1 \\
\hline & $\begin{array}{l}\text { Describing the structure of alkanes, alkenes, and } \\
\text { alkyne compounds based on their IUPAC names }\end{array}$ & Essay & 1 \\
\hline & $\begin{array}{l}\text { Naming the compounds alkanes, alkenes, and } \\
\text { alkyne }\end{array}$ & Objective & 3 \\
\hline & Deducing the relationships of the boiling points of & Objective & 1 \\
\hline & $\begin{array}{l}\text { hydrocarbons to their relative molecular masses } \\
\text { and structures }\end{array}$ & Essay & 1 \\
\hline & Determining structural isomers and geometric & Objective & 3 \\
\hline & isomers & Essay & 2 \\
\hline & $\begin{array}{l}\text { Writing down the equations for the oxidation } \\
\text { reactions for alkanes, alkenes, and alkyne } \\
\text { compounds }\end{array}$ & Objective & 3 \\
\hline & Writing down the equation for the substitution & Essay & 1 \\
\hline & reaction for alkanes & Objective & 1 \\
\hline & $\begin{array}{l}\text { Writing down the equation for the elimination } \\
\text { reaction equation for haloalkane compounds }\end{array}$ & Objective & 2 \\
\hline & Writing down the addition reaction equations for & Objective & 1 \\
\hline & alkenes, and alkyne compounds & Essay & 1 \\
\hline
\end{tabular}


indexes of the discriminating power. The results showed that for objective test items, the item validities were $.31-.66$, the reliability was .77 , the levels of difficulties were $.34-.83$, and the different power indexes were $.17-.72$. On the other hand for essay test items, the item validities were $.38-.81$, the reliability was .91 , the levels of difficulties were $.12-.84$, and the different power indexes were $.30-.68$. Meanwhile, a questionnaire was used to collect data related to students' responses to the learning strategies applied. The questionnaire consisted of four dimensions, including motivation, activities, conceptual mastery, and group collaboration. It was in the form of closed questions with four response options, namely, strongly agree, agree, disagree, and strongly disagree. It was validated by two content experts and classified as valid.

\section{Data Analysis}

The research data consisted of students' learning achievement and students' responses to the learning strategies applied. Data of students' learning achievement were analyzed by inferential statistical techniques, namely, analysis of covariance, at a significant level of $5 \%$. The assumption tests were done as prerequisites for the analysis of covariance. The assumption tests included the tests of normality, variance homogeneity, linearity, and slope homogeneity of regression lines. Meanwhile, data of students' responses were analyzed by descriptive statistical techniques.

\section{FINDINGS AND DISCUSSION \\ Findings}

\section{Data of Pretest and Posttest}

The learning achievement of students who learned to use the mind map learning strategy and the concept map learning strategy was in the form of pretest and posttest scores. Average scores and standard deviations of students' pretest and posttest scores in the Experimental Group 1 and 2 are presented in Table 2.

Table 2. Summary of Mean and Standard Deviation of the Pretest and Posttest

\begin{tabular}{lrrrrr}
\hline \multirow{2}{*}{ Statistics } & \multicolumn{2}{c}{ Pretest } & & \multicolumn{2}{c}{ Posttest } \\
\cline { 2 - 3 } \cline { 5 - 6 } \cline { 5 - 6 } & $\mathbf{X 1}$ & \multicolumn{1}{c}{$\mathbf{X 2}$} & & $\mathbf{X 1}$ & \multicolumn{1}{|c|}{$\mathbf{2}$} \\
\hline Mean & 19.58 & 20.90 & & 79.27 & 73.58 \\
$S D$ & 7.36 & 8.19 & & 9.23 & 8.63 \\
\hline
\end{tabular}

Note: $X 1=$ Experimental Group $1 ; X 2=$ Experimental Group 2

\section{Assumption Test Results}

The normality test of data distribution was carried out using the Shapiro-Wilk technique. The results of the normality test are presented in Table 3. Data in Table 3 showed that all the significant values were more than .05 . These results supported that all data were normally distributed.

Table 3. Results of the Normality Test

\begin{tabular}{lcccc}
\hline \multirow{2}{*}{ Test } & \multirow{2}{*}{$\begin{array}{c}\text { Experimental } \\
\text { Group }\end{array}$} & \multicolumn{3}{c}{ Shapiro-Wilk } \\
\cline { 3 - 5 } & 1 & Statistic & $\boldsymbol{d} \boldsymbol{f}$ & Sig. \\
\hline Pretest & 2 & .927 & 26 & .067 \\
\multirow{2}{*}{ Posttest } & 1 & .906 & 24 & .054 \\
& 2 & .973 & 26 & .712 \\
& & .953 & 24 & .308
\end{tabular}

The homogeneity variance test between groups was carried out using the Levene test. The homogeneity variance test results are presented in Table 4. Data in Table 4 indicated that all the significant values were more than .05 . These results supported that the variances of data for both the pretest and the posttest in both groups were homogeneous.

Table 4. Results of the Homogeneity Variance Test

\begin{tabular}{llcccc}
\hline Test & Description & $\begin{array}{c}\text { Levene } \\
\text { Statistic }\end{array}$ & $\boldsymbol{d f 1}$ & $\boldsymbol{d f 2}$ & Sig. \\
\hline Pretest & Based on mean & .408 & 1 & 48 & .526 \\
& Based on median & .273 & 1 & 48 & .604 \\
& Based on median and with adjusted df & .273 & 1 & 47.470 & .604 \\
& Based on trimmed mean & .419 & 1 & 48 & .521 \\
Posttest & .469 & 1 & 48 & .497 \\
& Based on mean & .578 & 1 & 48 & .451 \\
& Based on median & .578 & 1 & 47.317 & .451 \\
& Based on median and with adjusted df & .498 & 1 & 48 & .484 \\
\hline
\end{tabular}


The linearity test was conducted to determine the linear relationship between students' prior knowledge (pretest scores) and the students' learning achievement (posttest scores) in each group. The significances of the direction of the regression were shown by the significant values in rows of linearity in Table 5 and the linearities of the regression lines were indicated by the significant values in rows of the deviation from linearity in Table 5. All the significant values of the linearity were less than .05 . These results supported that the direction of regression was significant. Then, all the significant values of the deviation from linearity were more than .05 . These results also supported that the relationship between pretest and posttest was linear.

The slope homogeneity test of the regression lines was evidenced by the absence of interaction between covariate variables (pretest) and independent variables (the learning strategies). The significant value in the row of the strategy* pretest in Table 6 was more than .05 . This result evidenced that there was no interaction between covariate variables (pretest) and independent variables (the learning strategies).

Table 5. Results of the Linearity Test

\begin{tabular}{llrrrrr}
\hline $\begin{array}{l}\text { Experimental } \\
\text { Group }\end{array}$ & Criteria & $\begin{array}{c}\text { Sum of } \\
\text { squares }\end{array}$ & \multicolumn{1}{c}{$\boldsymbol{d f}$} & \multicolumn{1}{c}{$\begin{array}{c}\text { Mean } \\
\text { square }\end{array}$} & \multicolumn{1}{c}{$\boldsymbol{F}$} & Sig. \\
\hline 1 & Linearity & 1478.193 & 1 & 1478.193 & 48.821 & .000 \\
& Deviation from linearity & 287.590 & 12 & 23.966 & .792 & .654 \\
2 & Linearity & 472.349 & 1 & 472.349 & 8.237 & .018 \\
& Deviation from linearity & 727.401 & 13 & 55.954 & .976 & .531 \\
\hline
\end{tabular}

Table 6. Results of the Slope Homogeneity Test of the Regression Lines

\begin{tabular}{lccrrr}
\hline Sources & Type III Sum of Squares & $\boldsymbol{d} \boldsymbol{f}$ & Mean Square & $\boldsymbol{F}$ & Sig. \\
\hline Corrected model & 2404.497 & 3 & 801.499 & 19.995 & .000 \\
Intercept & 22389.098 & 1 & 22389.098 & 558.537 & .000 \\
Strategy & 10.443 & 1 & 10.443 & .261 & .612 \\
Pretest & 1908.896 & 1 & 1908.896 & 47.621 & .000 \\
Strategy*pretest & 154.400 & 1 & 154.400 & 3.852 & .056 \\
Error & 1843.923 & 46 & 40.085 & & \\
Total & 297167.000 & 50 & & & \\
Corrected total & 4248.420 & 49 & & & \\
\hline
\end{tabular}

\section{Hypothesis Test Results}

The assumption tests that had been done showed that all data met the requirements to be analyzed using the covariance analysis test. The significant value in the row of strategy in Table 7 was less than .05 . Thus, a decision could be made that the null hypothesis was rejected or the alternative hypothesis was accepted. In other words, there was a significant difference between the learning achievement of students who learned with the mind map learning strategy and the learning achievement of students who learned with the concept map learning strategy.

Table 7. Results of the Covariance Analysis Test

\begin{tabular}{lrrrrrr}
\hline Source & Type III Sum of Squares & $\boldsymbol{d} \boldsymbol{f}$ & Mean Square & \multicolumn{1}{c}{$\boldsymbol{F}$} & Sig. & Partial Eta Squared \\
\hline Corrected model & 2250.097 & 2 & 1125.048 & 26.461 & .000 & \\
Intercept & 22523.121 & 1 & 22523.121 & 529.737 & .000 & \\
Pretest & 1846.625 & 1 & 1846.625 & 43.432 & .000 & .480 \\
Strategy & 563.301 & 1 & 563.301 & 13.249 & .001 & .220 \\
Error & 1998.323 & 47 & 42.518 & & & \\
Total & 297167.000 & 50 & & & & \\
Corrected total & 4248.420 & 49 & & & & \\
\hline
\end{tabular}




\section{Students' Responses}

Students' responses to both learning strategies applied in this study were measured by the questionnaire containing 24 statement items. The dimensions measured in students' responses included four aspects, namely, (1) motivation, (2) activities, (3) mastery of concepts, and (4) group collaboration. The results of students' responses are shown in Table 8.

Table 8. Students' Responses to the Learning Strategies

\begin{tabular}{lccccc}
\hline \multirow{2}{*}{$\begin{array}{l}\text { Dimensions of } \\
\text { student responses }\end{array}$} & \multicolumn{2}{c}{ Group 1 } & & \multicolumn{2}{c}{ Group 2 } \\
\cline { 2 - 3 } \cline { 5 - 6 } \cline { 5 - 6 } & Mean & SD & & Mean & SD \\
\hline Motivation & 3.49 & .52 & & 3.30 & .47 \\
Activities & 3.46 & .56 & & 3.32 & .47 \\
Mastery of concepts & 3.34 & .49 & & 3.28 & .45 \\
Group collaboration & 3.45 & .54 & & 3.32 & .49 \\
Average & 3.45 & .53 & & 3.31 & .47 \\
\hline
\end{tabular}

\section{Discussion}

In both learning strategies, students made questions in their groups through $5 \mathrm{~W} 1 \mathrm{H}$ strategies (what, why, where, when, who, and how) in accordance with the learning objectives at each meeting. This step was intended to help students develop their understanding of the contents of subject matters. Next, students looked for answers to the questions they made by reading various information sources and conducting group discussions. These steps helped students to find the concepts learned so that the concepts constructed could be remembered longer (Vallori, 2014). In addition, in group discussions, students interacted more intensively with their peers to find and deepen new concepts. This is consistent with the view of student-centered learning.

After group discussions, students conducted class discussions. At this step, one group presented the answers to the questions generated in the group, which were then responded by other groups. This step was intended to confirm and to test the findings of students in group discussions.

Next, both learning strategies had different steps. In the mind map learning strategy, students mapped their answers in the form of mind maps in groups. At this step, students used the iMindMap 7 software to create mind maps. On the other hand, in the concept map learning strategy, students mapped their answers in the form of concept maps in groups. At this step, students used the Cmaptools software to create concept maps. The purposes of using this computer softwares were to help students mapped ideas and concepts so that they were easier to learn. The steps in creating mind and concept maps were focused on the way students think in processing the information they got during group discussions. Next, the results of mind and concept maps created by students were exhibited at the end of the meeting in each class. The mind and concept map exhibitions were intended to clarify the maps made by students. With the exhibitions, teachers could see a picture of students' content understanding.

The mind and concept maps were both graphical tools for describing and linking knowledge that was fully learned by students so that they understood the contents more easily. The mind maps were created by writing the main topic in the middle then followed by branches out of the main topic. Branches on mind maps were made in various shapes and colors generated from questions and answers by students. Meanwhile, concept maps were created by determining important concepts by students while searching for answers and then creating relationships between concepts. Each concept was written in a box or circle that was connected by lines containing connecting words.

It is important to map the ideas or concepts found by students during the learning process. Students who are able to describe complex relationships in the diagrams or maps tend to understand these relationships, remember them, and can analyze their parts (Davies, 2011). It is also supported by research results which reveal that the concept maps can help students understand, integrate, and clarify concepts and increase students' interest in learning (Chiou, 2014). The concept maps help low-achieving students to improve their learning outcomes (Karakuyu, 2010), encourage students to master contents at a high cognitive level, enable students to build a knowledge base (Awofala, 2011), enhance students' academic achievement (Cheema \& Mirza, 2013; Arokoyu \& Obunwo, 2014), improve students' retention (Adeniran, Ochu, \& Atoo, 2018). On the other hand, the mind maps can help students make their cognitive structure connections broader, more thematically 
organized, and richer (Dhindsa et al., 2011). The mind maps also allow students to understand contents more easily, connect between contents, and understand the whole concepts (Tungprapa, 2015).

In addition, the mind and concept maps can change the shapes of the contents that were originally in the forms of a long description into concise map forms that can help students remember contents that are learned more easily. Students understand the visual forms more easily than written descriptions or oral forms (Davies, 2011; Jackson, 2016). Therefore, the concept and mind maps in learning can make students remember and understand the contents more easily.

The results showed that students' learning achievement was better in the classes taught with the mind map learning strategy than the classes taught with the concept map learning strategy. This could be viewed in terms of graphics. The mind maps are more interesting than the concept maps because the mind maps are made free according to students' way of thinking and use many colors (Balim, 2013; Aydin, 2015). In addition, there are no restrictions on ideas created and there are no requirements to create particular structures or formats (Davies, 2011). When viewed from the creating process, the mind maps are easier to make than the concept maps because students only need to write questions, answers of questions, and all information obtained in learning as branches of the main topic, while on the concept maps students must first determine the important concepts and find relationships between concepts.

In the process of creating mind maps, both parts of the brain work because the mind maps involve visual aspects, nonverbal thinking, and creative thinking (the left parts of the brain) together with analytical thinking (the right parts of the brain). On the other hand, in the process of creating concept maps, students only use the left parts of the brain (Spoorthi, Prashanthi, \& Pandurangappa, 2013). If both parts of the brain are used together, students will easily concentrate and understand the contents of subject matters (Spoorthi et al., 2013; Liu et al., 2014). This is in line with the opinion of (Balim, 2013) which states that the mind maps are visualization tools and they are very helpful for students in remembering information in the learning process. Other researchers reported that mind maps can develop students' critical thinking skills (Ellozy \& Mostafa, 2010; Fuad, Zubaidah, Mahanal, \& Suarsini, 2017; RezapourNasrabad, 2019; Fitria, Floriasti, Djohan, \& Sittiprapaporn, 2020) and creative thinking skills (Miranti \& Wilujeng, 2018). Students become more responsive and more motivated in the mind maps learning environment (Wilson, Copeland-Solas, \& Guthrie-Dixon, 2016). The selection of learning models or strategies that are in line with students' learning styles will lead to students' satisfaction towards the learning done by teachers.

If viewed from the students' responses, students gave more positive responses to the mind map learning strategy than to the concept map learning strategy. Students felt more positive impacts on the aspects of activeness, motivation, mastery of concepts, and group collaboration in the mind map learning strategy. Students hoped that the mind learning strategy can be continued. These students' responses indicated that the mind map learning strategy was very feasible to apply and could be the learning strategy that was worth trying extensively on other subjects. It could be seen further that there was a positive relationship between the students' learning achievement and the students' responses on the application of the mind map learning strategy.

In the implementation of both learning strategies, there were several obstacles. These were as follows. At the beginning of the implementation of both learning strategies, students were still unable to adapt to the learning strategy applied, such as developing $5 \mathrm{~W} 1 \mathrm{H}$ questions, finding answers to questions in group discussions and creating the mind and concept maps based on the results of group discussions. For that, students were guided patiently to follow the steps of the learning process. Finally, students could adjust and follow the learning steps applied.

\section{CONCLUSION}

The qualified education absolutely must be carried out by every teacher. With the qualified education, the qualified human resources will be generated. To achieve the qualified education, teachers need to apply innovative learning models or strategies. Many innovative learning models or strategies have been developed to improve 
the quality of education. Two of the several innovative learning models or strategies are the mind map learning strategy and the concept map learning strategy. Both of these learning strategies are seen as effective in improving students' learning achievement. However, the big question is which of the two learning strategies is more effective? The results of testing the two learning strategies produce that the mind map learning strategy is more effective in improving students' learning achievement than the concept map learning strategy. Based on the results of this study, it can be suggested that teachers can apply the mind map learning strategy to improve students' learning achievement.

\section{REFERENCES}

Abbas, S. S., Eldin, A. S., \& Elsayed, A. (2018, September). The effect of concept mapping and mind mapping utilization on students' understanding level: An empirical study. Paper presented at the Eighth International Conference on Concept Mapping, Medellín, Colombia. http://cmc.ihmc.us/ cmc2018Papers/cmc2018-p77.pdf.

Adeniran, S. A., Ochu, N. O., \& Atoo, S. F. (2018). Effect of concept mapping strategy on students' retention in basic science in Benue State, Nigeria. International Journal of Research \& Review, 5(5), 193 200. https://www.ijrrjournal.com/IJRR Vol.5 Issue.5 May2018/IJRR0030.pdf.

Adodo, S. O. (2013). Effect of mind-mapping as a self-regulated learning strategy on students' achievement in basic science and technology. Mediterranean Journal of Social Sciences, 4(6), 163-172. https:// doi.org/10.5901/mjss.2013.v4n6p163.

Arokoyu, A., \& Obunwo, J. C. (2014). Conceptmapping: An instructional strategy for retention of organic chemistry concepts. International Journal of Scientific Research and Innovative Technology, 1(3), 50-57. https://www.ijsrit.com/ details.php?month=201410.

Awad, K. T., \& Hegazy, A. M. (2015). The effect of using digital mind mapping on cognitive achievement and performance level of some basic skills in handball.
Turkish Journal of Kinesiology, 1(1), 25-31. https://dergipark.org.tr/en/pub/ turkjkin/issue/22292/239078.

Awofala, A. O. A. (2011). Effect of concept mapping strategy on students' achievement in junior secondary school mathematics. International Journal of Mathematics Trends and Technology, 2(3), 11-16. http://ijmttjournal.org/Volume-2/issue-3/ IJMTT-V2I3P504.pdf.

Aydin, G. (2015). The effects of technologysupported mind and concept mapping on students' construction of science concepts the effect of mind mapping in science education. Anthropologist, 20(1-2), 166-176. https://www.mindmeister.com/ generic files/get file/8066270?filetype $=\mathrm{a}$ ttachment file.

Balim, A. G. (2013). The Effect of mind-mapping applications on upper primary students success and inquiry learning skills in science and environment education. International Research in Geographical and Environmental Education, 22(4), 337-352. https://doi.org/10.1080/103820 46.2013.826543.

Brinkerhoff, J. L., \& Booth, G. M. (2013). The effect of concept mapping on student achievement in an introductory non-majors biology class. European International Journal of Science and Technology, 2(8), 43-72. https://eijst.org. uk/vol-2-no-8-october-2013/.

Chang, J. H., Chiu, P. S. \& Huang, Y.M. (2018). A sharing mind map-oriented approach to enhance collaborative mobile learning with digital archiving systems. International Review of Research in Open and Distributed Learning, 19(1), 1-24. https://doi.org/10.19173/irrodl. v19i1.3168.

Chawla, J. (2015). Effect of concept mapping strategy on achievement in chemistry of IX graders in relation to gender. International Journal of Science and Research (IJSR), 4(12), 531-536. https://doi.org/10.21275/ v4i12.nov151817. 
Cheema, A. B., \& Mirza, M. S. (2013). Effect of concept mapping on students' academic achievement. Journal of Research and Reflections in Education, 7(2), 125-132. https://tehqeeqat.com/downloadpdf/2508.

Chiou, C. -C. (2014). The effect of concept mapping on students' learning achievements and interests. Innovations in Education and Teaching International, 45(4), 375-387. https://doi. org/10.1080/14703290802377240.

Chiou, C.-C., Lee, L.-T., Tien, L.-C., \& Wang, Y.-M. (2017). Analyzing the effects of various concept mapping techniques on learning achievement under different learning styles. Eurasia Journal of Mathematics, Science and Technology Education, 13(7), 3687-3708. https://doi. org/10.12973/eurasia.2017.00753a.

D’Antoni, A. V., Zipp, G. P., Olson, V. G., \& Cahill, T. F. (2010). Does the mind map learning strategy facilitate information retrieval and critical thinking in medical students? BMC Medical Education, 10(1), 1-11. https://doi.org/10.1186/1472-692010-61.

Davies, M. (2011). Concept mapping, mind mapping, and argument mapping: What are the differences and do they matter? Higher Education, 62(3), 279-301. https:// doi.org/10.1007/s10734-010-9387-6.

Dhindsa, H. S., Kasim, M., \& Anderson, O. R. (2011). Constructivist-visual mind map teaching approach and the quality of students' cognitive structures. Journal of Science Education and Technology, 20(2), 186-200. https://doi.org/10.1007/s10956010-9245-4.

Eison, J. (2010). Using active learning instructional strategies to create excitement and enhance learning. https:// www.ualberta.ca/centre-for-teachingand-learning/media-library/teachinginstitute/2019/redefining-student-success/ active-learning---creating-excitement-inthe-classroom---handout.pdf.

Ellozy, A. R., \& Mostafa, H. M. H. (2010). Making learning visible: Using e-maps to enhance critical reading skills. MERLOT Journal of Online Learning and Teaching, 6(3), 634-646. https://jolt.merlot.org/ vol6no3/ellozy 0910.pdf.

Fadillah, A., Dewi, N. P. L. C., Ridho, D., Majid, A. N., \& Prastiwi, M. N. B. (2017). The effect of application of contextual teaching and learning (CTL) model-based on lesson study with mind mapping media to assess student learning outcomes on chemistry on colloid systems. International Journal of Science and Applied Science: Conference Series, 1(2), 101-108. https:// doi.org/10.20961/ijsascs.v1i2.5128.

Fitria, Y. J., Floriasti, T. W., Djohan, \& Sittiprapaporn, P. (2020). Mind mapping tool increased critical thinking through blended learning. Asian Journal of Medical Sciences, 11(1), 42-50. https:// doi.org/10.3126/ajms.v11i1.26516.

Fuad, N. M., Zubaidah, S., Mahanal, S., \& Suarsini, E. (2017). Improving junior high schools' critical thinking skills based on test three different models of learning. International Journal of Instruction, 10(1), 101-116. https://doi.org/10.12973/ iji.2017.1017a.

Herlanti, Y., Mardiati, Y., Wahyuningtyas, R., Mahardini, E., Iqbal, M., \& Sofyan, A. (2017). Discovering learning strategy to increase metacognitive knowledge on biology learning in secondary school. Jurnal Pendidikan IPA Indonesia, 6(1), 179-186. https://doi.org/10.15294/jpii. v6il.9605.

Hu, M.-L. M., \& Wu, M.-H. (2012). The effect of concept mapping on students' cognitive load. World Transactions on Engineering and Technology Education, 10(2), 134137. http://www.wiete.com.au/journals/ WTE\&TE/Pages/TOC V10N2.html.

Hwang, G.-J., Wu, C.-H., \& Kuo, F.-R. (2013). Effects of touch technology-based concept mapping on students' learning attitudes and perceptions. Journal of Educational Technology \& Society, 16(3), 274-285. https://www.jstor.org/stable/ jeductechsoci.16.3.274. 
Hwang, G.-J., Kuo, F.-R., Chen, N.-S., \& Ho, H.-J. (2014). Effects of an integrated concept mapping and web-based problemsolving approach on students' learning achievements, perceptions and cognitive loads. Computers and Education, 71, 77-86. https://doi.org/10.1016/j. compedu.2013.09.013.

Hwang, G.-J., Shi, Y.-R., \& Chu, H.-C. (2011). A concept map approach to developing collaborative Mindtools for context-aware ubiquitous learning. British Journal of Educational Technology, 42(5), 778789. https://doi.org/10.1111/j.1467$\underline{8535.2010 .01102 . x}$.

Ismail, M. N., Ngah, N. A., \& Umar, I. N. (2010). The effects of mind mapping with cooperative learning on programming performance, problem solving skill and metacognitive knowledge among computer science students. Journal of Educational Computing Research, 42(1), 35-61. https://doi.org/10.2190/EC.42.1.b.

Jackson, Jr., E. B.. (2016). Concept mapping: Developing critical thinking through mind mapping. https://silo.tips/download/ concept-mapping-developing-criticalthinking-through-mind-mapping.

Karakuyu, Y. (2010). The effect of concept mapping on attitude and achievement in a physics course. International Journal of the Physical Sciences, 5(6), 724-737. https://academicjournals.org/journal/ IJPS/article-full-text-pdf/536E2A726759.

Khodadady, E., \& Ghanizadeh, A. (2011). The impact of concept mapping on EFL learners' critical thinking ability. English Language Teaching, 4(4), 49-60. https:// doi.org/10.5539/elt.v4n4p49.

Kilic, M., \& Çakmak, M. (2013). Concept maps as a tool for meaningful learning and teaching in chemistry education. International Journal on New Trends in Education and Their Implications, 4(4), 152-164. http://www.ijonte.org/ FileUpload/ks63207/File/14.kilic.pdf.

Lestari, F., Saryantono, B., Syazali, M., Saregar,
A., Madiyo, Jauhariyah, D., \& Umam, R. (2019). Cooperative learning application with the method of network tree concept map: Based on Japanese learning system approach. Journal for the Education of Gifted Young Scientists, 7(1), 15-32. https://doi.org/10.17478/jegys.471466.

Liu, P.-L., Chen, P.-L., \& Chang, Y.-J. (2010). Effects of a computer-assisted concept mapping learning strategy on EFL college students' English reading comprehension. Computers and Education, 54(2), 436-445. https://doi.org/10.1016/j. compedu.2009.08.027.

Liu, Y., Zhao, G., Ma, G., \& Bo, Y. (2014). The effect of mind mapping on teaching and learning: A meta-analysis. Standard Journal of Education and Essay, 2(1), 17-31. https://www.researchgate.net/ publication/297833919 The Effect of_Mind_Mapping_on_Teaching_and Learning_A Meta-Analysis.

Mahasneh, A. M. (2017). The effect of using electronic mind mapping on achievement and attitudes in an introduction to educational psychology course. New Educational Review, 47(1), 295-304. https://doi.org/10.15804/ tner.2017.47.1.23.

Miranti, M. G., \& Wilujeng, B. Y. (2017, 12 September). Creative thinking skills enhancement using mind mapping. Paper presented at $1^{\text {st International Conference on }}$ Social, Applied Science and Technology in Home Economics (ICONHOMECS 2017), Surabaya, Indonesia. https://doi. org/10.2991/iconhomecs-17.2018.9.

Prastiwi, D., Haryani, S., \& Lisdiana, L. (2018). The effectiveness of guided inquiry with mind mapping to improve science process skills and learning motivation. Journal of Primary Education JPE, 7(2), 195-203. https://journal.unnes.ac.id/sju/index.php/ jpe/article/view/23535.

Rezapour-Nasrabad, R. (2019). Mind map learning technique: An educational interactive approach. International Journal of Pharmaceutical Research, 
11(1), 1593-1597. http://www.ijpronline. com/ViewArticleDetail.aspx?ID=10822.

Si, J., Kong, H.-H., \& Lee, S.-H. (2018). Developing clinical reasoning skills through argumentation with the concept map method in medical problem-based learning. Interdisciplinary Journal of Problem-Based Learning, 13(1), 1-11. https://doi.org/10.7771/1541-5015.1776.

Spoorthi, B. R., Prashanthi, C., \& Pandurangappa, R. (2013). Mind Mapping-an effective learning adjunct to acquire a tsunami of information. International Journal of Scientific Research and Publication, 3(12), 1-4. http://www.ijsrp.org/researchpaper-1213.php?rp=P242102.

Susilawati, A., Hernani, H., \& Sinaga, P. (2017). The application of project-based learning using mind maps to improve students' environmental attitudes towards waste management in junior high schools. International Journal of Education, 9(2), 120-125. https://doi.org/10.17509/ije. v9i2.5466.

Tanriseven, I. (2014). A tool that can be effective in the self-regulated learning of pre-service teachers: The mind map. Australian Journal of Teacher Education, 39(1), 65-80. https://doi.org/10.14221/ ajte.2014v39n1.1.

Tarkashvand, Z. (2015). Male learners vocabulary achievement through concept mapping and mind mapping: Differences and similarities. Educational Research and Reviews, 10(7), 790-798. https://doi. org/10.5897/err2015.2158.
Tungprapa, T. (2015). Effect of using the electronic mind map in the educational research methodology course for masterdegree students in the faculty of education. International Journal of Information and Education Technology, 5(11), 803-807. https://doi.org/10.7763/IJIET.2015. $\underline{\text { V5.615. }}$

Ültanır, E. (2012). An Epistemological Glance at the constructivist approach: Constructivist learning in Dewey, Piaget, and Montessori. International Journal of Instruction, 5(2), 195-212. http://www.eiii.net/volumes/318-july-2012-volume-5number-2.

Vallori, A. B. (2014). Meaningful learning in the practice. Journal of Education and Human Development, 3(4), 199-209. https://doi. org/10.15640/jehd.v3n4a18.

Wilson, K., Copeland-Solas, E., \& GuthrieDixon, N. (2016). A Preliminary study on the use of mind mapping as a visual learning strategy in general education science classes for Arabic speakers in the United Arab Emirates. Journal of the Scholarship of Teaching and Learning, 16(1), 31-52. https://doi.org/10.14434/ josotl.v16i1.19181.

Zubaidah, S., Fuad, N. M., Mahanal, S., \& Suarsini, E. (2017). Improving creative thinking skills of students through differentiated science inquiry integrated with mind map. Journal of Turkish Science Education, 14(4), 77-91. http:// www.tused.org/index.php/tused/article/ view/175/131. 